\title{
Evaluating the Volatility of Market Risk of Vietnam Construction Industry After the Low Inflation Period 2015-2017
}

ISSN: 2637-8078

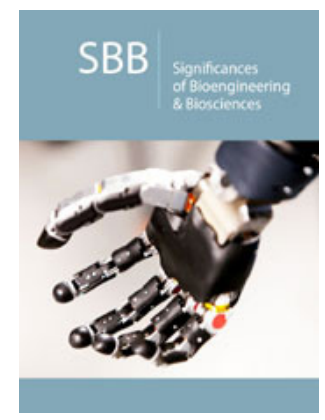

*Corresponding author: Dinh Tran Ngoc $\mathrm{Hu}$, Banking University, MBA, Chi Minh city Vietnam, International University of Japan, Niigata, Japan

Submission: 㭗 October 14, 2019

Published: 泚January 16, 2020

Volume 3 - Issue 5

How to cite this article: Dinh Tran Ngoc Hu. Evaluating the Volatility of Market Risk of Vietnam Construction Industry After the Low Inflation Period 20152017. Significances Bioeng Biosci.3(5). SBB.000575.2019.

DOI: $10.31031 /$ SBB.2020.03.000575

Copyright@ Dinh Tran Ngoc Hu, This article is distributed under the terms of the Creative Commons Attribution 4.0 International License, which permits unrestricted use and redistribution provided that the original author and source are credited.

\section{Dinh Tran Ngoc Hu*1}

${ }^{1}$ Banking University, MBA, Chi Minh city Vietnam, International University of Japan, Niigata, Japan

\begin{abstract}
The Vietnam economy has gained lots of achievements after the financial crisis 2007-2011, until it reached a low inflation rate of $0.6 \%$ in 2015 . This paper measures the volatility of market risk in Vietnam construction industry after this period (2015-2017). The main reason is the vital role of the construction company group in Vietnam in the economic development and growth in recent years always go with risk potential and risk control policies. This research paper aims to figure out how much increase or decrease in the market risk of Vietnam construction firms during the post-low inflation period 2015-2017. First, by using quantitative combined with comparative data analysis method, we find out the risk level measured by equity beta mean in the construction industry is acceptable, i.e. it is little lower than (<) 1 .

Then, one of its major findings is the comparison between risk level of construction industry during the financial crisis 2007-2009 compared to those in the post low inflation time 2015-2017. In fact, the research findings show us market risk fluctuation, measured by equity beta var, during the post low inflation time has increased moderately. Finally, this paper provides some ideas that could provide companies and government more evidence in establishing their policies in governance. This is the complex task, but the research results show us warning that the market risk volatility might be higher during the post low inflation period 2015-2017. And our conclusion part will recommend some policies and plans to deal with it. JEL classification numbers: G00, G390, C83
\end{abstract}

Keywords: Risk management; Asset beta; Financial crisis; Construction industry; Policy

\section{Introduction}

Throughout many recent years, Vietnam construction market is evaluated as one of active markets, which has certain positive effect for the economy. The development of construction industry goes parallel with real estate and construction material markets. And Vietnam construction firms take advantages of providing real estate assets with high quality but low cost. Central banks aim to maintain inflation around $2 \%$ to $3 \%$. Increases in inflation significantly beyond this range can lead to possible hyperinflation, a devastating scenario in which inflation rises rapidly out of control. Looking at exhibit 1, we can see the Vietnam economy has controlled inflation well. High inflation might lead to higher lending rate and harm the construction industry because of rising construction material price. This study will calculate and figure out whether the market risk level during the post-low inflation time (2015-17) has increased or decreased, compared to those statistics in the financial crisis time (2007-2009). The paper is organized as follows: after the introduction it is the research issues, literature review, conceptual theories and methodology. Next, section 3 will cover main research findings/results. Section 4 gives us some discussion and conclusion and policy suggestion will be in the section 5 .

\section{Body of Manuscript}

\section{Research issues}

The scope of this study is

A. Issue 1: Whether the risk level of construction firms under the different changing 
scenarios in post-low inflation period 2015-2017 increase or decrease so much, compared to in financial crisis 2007-2009 and?

B. Issue 2: Because Viet Nam is an emerging and immature financial market and the stock market still in the starting stage, whether the dispersed distribution of beta values become large in the different changing periods in the construction industry.

This paper also tests three (3) below hypotheses

A. Hypothesis 1: Comparing two (2) periods, during the financial crisis impact, the beta or risk level of listed companies in construction industry will relatively higher than those in the postlow inflation environment.

B. Hypothesis 2: Because Viet Nam is an emerging and immature financial market and the stock market still in the recovering stage, there will be a large disperse distribution in beta values estimated in the construction industry.

C. Hypothesis 3: With the above reasons, the mean of equity and asset beta values of these listed construction firms tend to impose a high-risk level, i.e., beta should higher than (>) 1. This hypothesis is based on the context of emerging markets including Viet Nam where there lacks enough information and data disclosure although it might have high growth rate.

\section{Literature Review}

Eugene FF et al. [1] also indicated in the three-factor model that "value" and "size" are significant components which can affect stock returns. They also mentioned that a stock's return not only depends on a market beta, but also on market capitalization beta. The market beta is used in the three-factor model, developed by Fama [1], which is the successor to the CAPM model by Sharpe, Treynor and Lintner.

Dimitrov [2] documented a significantly negative association between changes in financial leverage and contemporaneous risk-adjusted stock returns. Umar [3] found that firms which maintain good governance structures have leverage ratios that are higher (forty-seven percent) than those of firms with poor governance mechanisms per unit of profit. Chen et al. [4] supported regulators' suspicions that over-reliance on short-term funding and insufficient collateral compounded the effects of dangerously high leverage and resulted in undercapitalization and excessive risk exposure for Lehman Brothers. The model reinforces the importance of the relationship between capital structure and risk management. And Gunaratha [5] revealed that in different industries in Sri Lanka, the degree of financial leverage has a significant positive correlation with financial risk.

During the financial crisis 2007-2009 in Vietnam and global financial markets, high inflation causing high lending rates to have created risks for many industries such as real estate and the whole economy. Mohamad et al. [6] showed that financial risk is vital through using both return on asset and return on equity in the performance equation. This result also implied that we cannot avoid the inverse relation of financial risk and performance; therefore, bank system would be better to make a trade-off between risk and performance. Wang et al. [7] presented results showing that firms with long-term institutional investors receive significantly positive abnormal returns around the offering announcement. Then, Gunarathna [8] revealed that whereas firm size negatively impacts on the financial risk, financial leverage and financial risk has positive relationship. Hami (2017) showed that financial depth has been affected negatively by inflation in Iran during the observation period. Park et al. [9] found that sentiment caused by investors' inattentiveness mainly drives the underlying potent relationship between investor sentiment and aggregate stock returns. The results accord with the notion that investor attention generally improves market efficiency.

\section{Conceptual Theories}

Positive sides of low inflation: Low (not negative) inflation reduces the potential of economic recession by enabling the labor market to adjust more quickly in a downturn and reduces the risk that a liquidity trap prevents monetary policy from stabilizing the economy [10]. This is explaining why many economists nowadays prefer a low and stable rate of inflation. It will help investment, encourage exports and prevent boom economy. Negative side of low inflation: it leads to low aggregate demand and economic growth, recession potential and high unemployment [11]. Production becomes less vibrant. Low inflation makes real wages higher. Workers can thus reduce the supply of labor and increase rest time. On the other hand, low product prices reduce production motivation. The central bank can use monetary policies, for instance, increasing interest rates to reduce lending, control money supply or the Ministry of finance and the government can use tight fiscal policy (high tax) to achieve low inflation [12].

Financial and credit risk in the bank system can increase when the financial market becomes more active and bigger, esp. with more international linkage influence [13]. This affects to risk increasing in construction and real estate sector. Hence, central banks, commercial banks, construction firms and the government need to organize data to analyze and control these risks, including market risk.

\section{Methodology}

We use the data from the stock exchange market in Vietnam (HOSE and HNX) during the financial crisis 2007-2009 period and the post -low inflation time 2015-2017 to estimate systemic risk results [14]. We perform both fundamental data analysis and financial techniques to calculate equity and asset beta values.

In this study, analytical research method and specially, comparative analysis method is used, combined with quantitative data analysis. Analytical data is from the situation of listed construction firms in VN stock exchange. Specifically, stock price data is from live data on HOSE stock exchange for 3 years 2015-2017, which presents the low inflation environment [15-21]. Then, we use both analytical and summary method to generate analytical results from data calculated. Finally, we use the results to suggest policy for both these enterprises, relevant organizations and government. 


\section{Main Results}

\section{General data analysis}

We get some analytical results from the research sample with 20 listed firms in the construction market with the live date from the stock exchange.

\section{Empirical research findings and discussion}

In the below section, data used are from total 20 listed construction industry companies on VN stock exchange (HOSE and HNX mainly). Different scenarios are created by comparing the calculation risk data between 2 periods: the post low inflation period 2015-2017 and the financial crisis 2007-2009. Market risk (beta) under the impact of tax rate, includes: 1) equity beta; and 2) asset beta. We model our data analysis as in the Figure 1:

Based on the above calculation result table, we analyze data as follows
Firstly, we see in the (Table 1) that more construction firms (8 over 20 firms) have equity beta values lower $(<$ ) than 1 , which means risk level acceptable. There are 4 firms (LM3, MCG, DIG, CNT) with equity beta $>1$ And 5 companies with negative equity beta $(<0)$. And (Table 2 ) provides evidence for us to see that equity beta mean of the sample is 0.358 , just little lower than $(<) 1$. It is acceptable. Then, looking at the (Table 3), we recognize that there are 4 firms with equity beta values $>1$ in the post-low inflation period 2015-17, compared to 6 firms with equity beta values $>1$ in the financial crisis 2007-2009 (Table 4). Next, (Table 5) shows that equity beta var in the post low inflation period are higher $(>)$ than those in the financial crisis 2007-2009. Furthermore, Table 5 tells us equity beta max in the post-inflation period 2015-2017 are higher ( $>$ ) than that in the financial crisis 2007-2009, whereas asset and equity beta mean are smaller $(<)$ than those in the financial crisis 2007-2009.

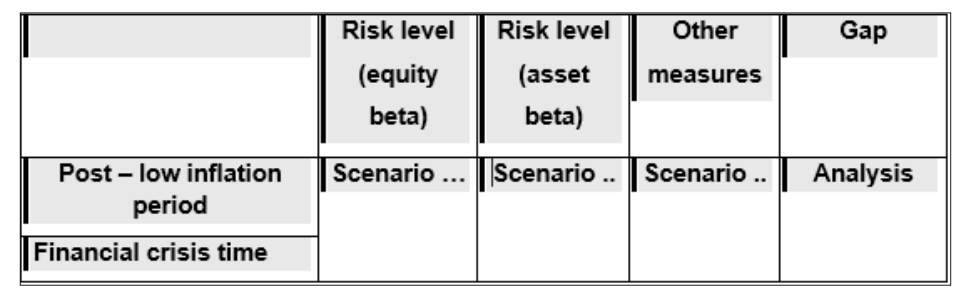

Figure 1: Analyzing market risk under two (2) scenarios: post-low inflation period 2015-2017 compared to the financial crisis 2007-2009.

Table 1 The Volatility of Market Risk (beta) of Construction Industry in the post- low inflation period 2015-2017.

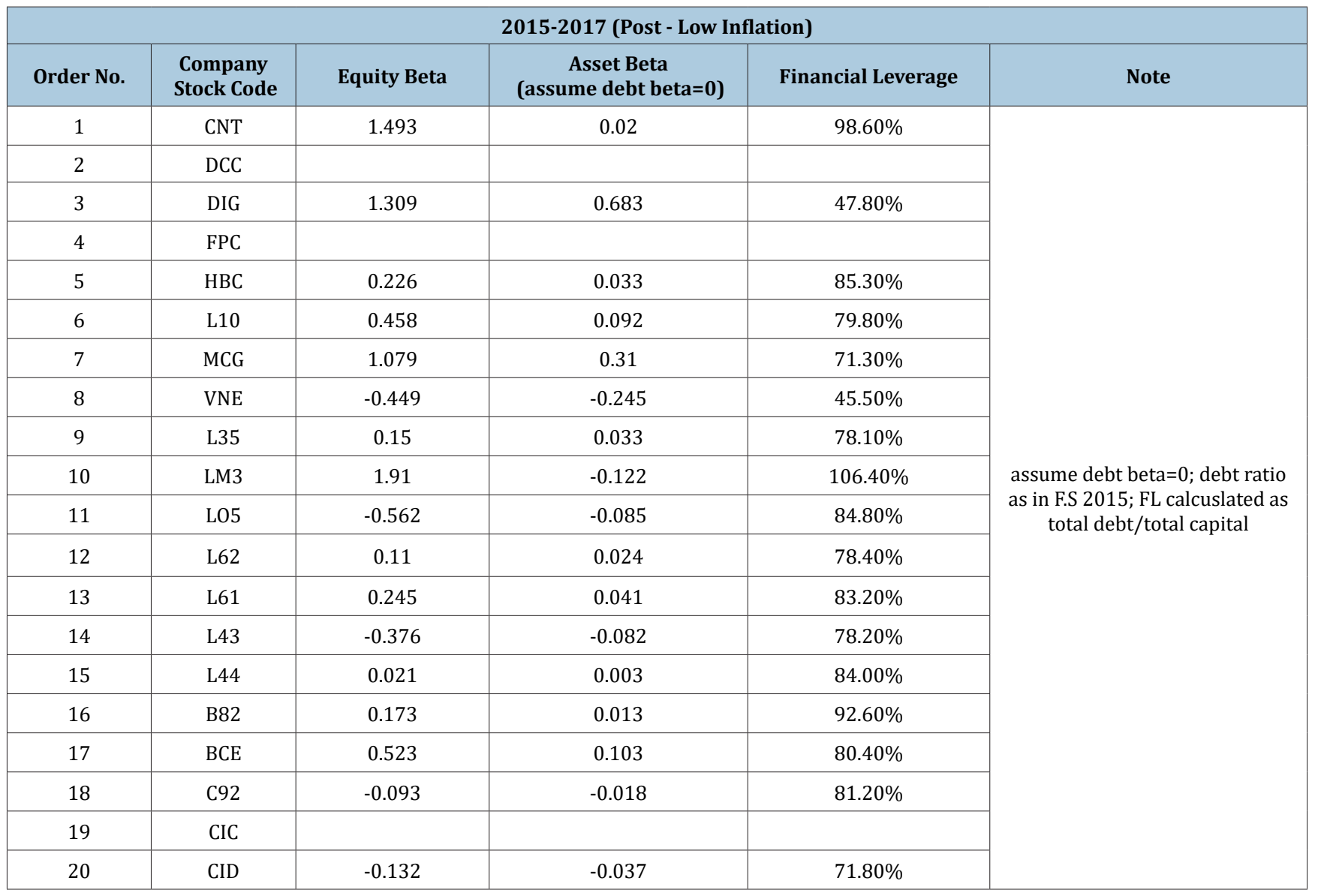


Table 2: The Statistics of Volatility of Market Risk (beta) of Construction Industry in the post-low inflation period 20152017.

\section{5-2017 (Post - Low Inflation)}

\begin{tabular}{|c|c|c|}
\hline Statistic Results & Equity Beta & Asset Beta (assume debt beta=0) \\
\hline MAX & 1.91 & -0.245 \\
\hline MIN & -0.562 & 0.045 \\
\hline MEAN & 0.358 & 0.0402 \\
\hline VAR & 0.4951 & \\
\hline
\end{tabular}

Table 3: The Comparison of Volatility of Market Risk (beta) of Construction Industry in the post-low inflation period 2015-2017 and the financial crisis 2007-2009.

\begin{tabular}{|c|c|c|c|c|c|c|}
\hline \multicolumn{7}{|c|}{ 2007-2009 (Financial Crisis) } \\
\hline Order No. & $\begin{array}{l}\text { Company } \\
\text { Stock Code }\end{array}$ & Equity Beta & $\begin{array}{c}\text { Asset Beta } \\
\text { (assume debt } \\
\text { beta=0) }\end{array}$ & Equity Beta & $\begin{array}{c}\text { Asset Beta } \\
\text { (assume debt } \\
\text { beta=0) }\end{array}$ & Note \\
\hline 1 & CNT & 1.062 & 0.134 & 1.493 & 0.02 & \\
\hline 2 & DCC & 1.299 & 0.578 & 0 & 0 & \\
\hline 3 & DIG & 1.772 & 0.964 & 1.309 & 0.683 & \\
\hline 4 & FPC & 0.484 & 0.229 & 0 & 0 & \\
\hline 5 & HBC & 1.03 & 0.277 & 0.226 & 0.033 & \\
\hline 6 & L10 & 0.909 & 0.193 & 0.458 & 0.092 & \\
\hline 7 & MCG & 1.595 & 0.543 & 1.079 & 0.31 & \\
\hline 8 & VNE & 1.7 & 0.606 & -0.449 & -0.245 & \\
\hline 9 & L35 & 0.295 & 0.095 & 0.15 & 0.033 & \\
\hline 10 & LM3 & 0.337 & 0.04 & 1.91 & -0.122 & \\
\hline 11 & LO5 & 0.745 & 0.179 & -0.562 & -0.085 & $\begin{array}{l}\text { assume debt beta }=0 \text {; debt ratio as in } \\
\text { F.S } 2015 \text { and } 2008\end{array}$ \\
\hline 12 & L62 & 0.606 & 0.171 & 0.11 & 0.024 & \\
\hline 13 & L61 & 0.856 & 0.261 & 0.245 & 0.041 & \\
\hline 14 & L43 & 0.709 & 0.217 & -0.376 & -0.082 & \\
\hline 15 & L44 & 1.277 & 0.252 & 0.021 & 0.003 & \\
\hline 16 & B82 & 0.86 & 0.146 & 0.173 & 0.013 & \\
\hline 17 & BCE & 0.955 & 0.515 & 0.523 & 0.103 & \\
\hline 18 & C92 & 0.8 & 0.121 & -0.093 & -0.018 & \\
\hline 19 & $\mathrm{CIC}$ & 0.919 & 0.248 & 0 & 0 & \\
\hline 20 & CID & 0.891 & 0.423 & -0.132 & -0.037 & \\
\hline
\end{tabular}


Table 4: The Difference between Volatility of Market Risk (beta) of Construction Industry in the post-low inflation period 2015-2017 and the financial crisis 2007-2009.

\begin{tabular}{|c|c|c|c|c|}
\hline \multicolumn{5}{|c|}{ GAP (+/-) 2015-17 Compared to 2007-09 } \\
\hline Order No. & Company Stock Code & Equity Beta & $\begin{array}{c}\text { Asset Beta } \\
\text { (assume debt beta=0) }\end{array}$ & Note \\
\hline 1 & CNT & -0.431 & 0.114 & \multirow{20}{*}{ values (2015-17) minus (-) 2007-09 } \\
\hline 2 & DCC & 1.299 & 0.578 & \\
\hline 3 & DIG & 0.463 & 0.281 & \\
\hline 4 & FPC & 0.484 & 0.229 & \\
\hline 5 & HBC & 0.804 & 0.244 & \\
\hline 6 & L10 & 0.451 & 0.101 & \\
\hline 7 & MCG & 0.516 & 0.233 & \\
\hline 8 & VNE & 2.149 & 0.851 & \\
\hline 9 & L35 & 0.145 & 0.062 & \\
\hline 10 & LM3 & -1.573 & 0.162 & \\
\hline 11 & L05 & 1.307 & 0.264 & \\
\hline 12 & L62 & 0.496 & 0.147 & \\
\hline 13 & L61 & 0.611 & 0.22 & \\
\hline 14 & L43 & 1.085 & 0.299 & \\
\hline 15 & L44 & 1.256 & 0.249 & \\
\hline 16 & B82 & 0.687 & 0.133 & \\
\hline 17 & BCE & 0.432 & 0.412 & \\
\hline 18 & C92 & 0.893 & 0.139 & \\
\hline 19 & CIC & 0.919 & 0.248 & \\
\hline 20 & CID & 1.023 & 0.46 & \\
\hline
\end{tabular}

Table 5: Statistics of Volatility of Market Risk (beta) of Construction Industry in the post-low inflation period 2015-2017 compared to those in the financial crisis 2007-2009.

\begin{tabular}{|c|c|c|c|c|c|c|}
\hline & $\begin{array}{l}\text { 2007-2009 } \\
\text { (Crisis) }\end{array}$ & & $\begin{array}{l}\text { 2015-2017 (Post } \\
\text { - Low Inflation) }\end{array}$ & & $\begin{array}{c}\text { GAP (+/-) 2015- } \\
17 \text { Compared to } \\
2007-09\end{array}$ & \\
\hline Statistic Results & Equity Beta & $\begin{array}{c}\text { Asset Beta } \\
\text { (assume debt beta=0) }\end{array}$ & Equity Beta & $\begin{array}{c}\text { Asset Beta } \\
\text { (assume debt } \\
\text { beta=0) }\end{array}$ & Equity Beta & $\begin{array}{c}\text { Asset Beta } \\
\text { (assume debt } \\
\text { beta=0) }\end{array}$ \\
\hline MAX & 1.772 & 0.964 & 1.91 & 0.683 & 0.138 & -0.281 \\
\hline MIN & 0.295 & 0.04 & -0.562 & -0.245 & -0.857 & -0.285 \\
\hline MEAN & 0.955 & 0.31 & 0.358 & 0.045 & -0.597 & -0.264 \\
\hline VAR & 0.1678 & 0.0518 & 0.495 & 0.04 & 0.327 & -0.012 \\
\hline $\begin{array}{l}\text { Note: Sample } \\
\text { size: } 20\end{array}$ & & & & & & \\
\hline
\end{tabular}

In addition to Figure 2 we can find out more clearly, Values of equity beta max and equity beta var in the post-low inflation 20152017 are higher ( $>$ ) than those in the crisis 2007-2009 while equity beta mean and asset beta mean are just little smaller $(<)$ than those in the financial crisis 2007-2009. It means that the level of risk in the post low inflation period 2015-17 is lower in general and in average, although the fluctuation in risk level measured by equity beta var is higher during the post-low inflation time.

\section{Discussion for Further Researches}

We can continue to analyze risk factors behind the risk scene (risk fluctuation increasing, shown by equity beta var as above analysis) in order to recommend suitable policies and plans to control market risk better. 


\section{Conclusion and Policy Suggestion}

In general, construction company group in Vietnam has been contributing significantly to the economic development and GDP growth rate of more than $6-7 \%$ in recent years. The above analysis shows us that despite of market risk decreasing, risk volatility (equity beta var) is increasing during the post-low inflation period. Construction firms in Vietnam need to continue increase their corporate governance system, structure and mechanisms, as well as their competitive advantage to control risk better. Also, they need to reduce risk of quality of real estate assets and reputation risk of construction companies. This research paper provides evidence that the market risk potential might be lower in $2015-2017$ postlow inflation period (looking again chart 1 equity beta mean values), while the Exhibit 3 also suggests that the credit growth rate increased in 2016 and slightly decrease in later years (2017-2018).
It means that the local economy is trying to control credit growth reasonably, however we need to analyze risk factors more carefully to reduce more market risk.

Looking at the above Figure 2, the result rejects the hypothesis 3 mentioning that the mean of equity and asset beta values of these listed construction firms tend to impose a little high-risk level, i.e., beta should higher than (>) 1. Because the equity beta mean is lower in the post-low (L) inflation period, it supports the hypothesis 1 saying that comparing two (2) periods, during the financial crisis impact, the beta or risk level of listed companies in construction industry will relatively higher than those in the post-low inflation environment. Additionally, the above result supports the hypothesis 2 stating that because Viet Nam is an emerging and immature financial market and the stock market still in the recovering stage, there will be a large disperse distribution in beta values estimated in the construction industry.

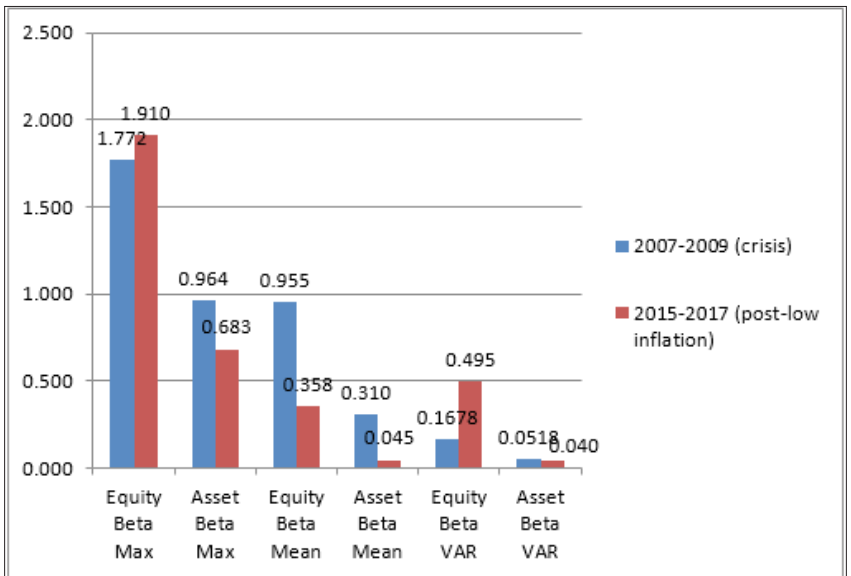

Figure 2: Statistics of Market risk (beta) in VN Construction industry in the post-low inflation period 20152017 compared to the financial crisis 2007-2009.

Last but not least, as it generates the warning that the risk fluctuation might be higher in the post-low inflation period, the government and relevant bodies such as Ministry of Finance and State Bank of Vietnam need to consider proper policies (including a combination of fiscal, monetary, exchange rate and price control policies) aiming to reduce the risk volatility and hence, help the construction system as well as the whole economy become more stable in next development stage. The Ministry of Finance continue to increase the effectiveness of fiscal policies and tax policies which are needed to combine with other macro policies at the same time. The State Bank of Viet Nam continues to increase the effectiveness of capital providing channels for construction companies as we could note that in this study, debt leverage has impacts on reducing risk level. Finally, this study opens some new directions for further researches in risk control policies in construction system as well as in the whole economy.

\section{References}

1. Eugene FF, French KR (2004) The Capital asset pricing model: Theory and evidence. Journal of Economic Perspectives 18(3): 25-46.

2. Dimitrov V, Jain PC (2006) The value relevance of changes in financial leverage. SSRN Working Paper pp. 1-46.
3. Umar (2011) Profits, financial leverage and corporate governance. SSRN Working Paper Research pp. 1-55.

4. Chen RR, Chidambaran NK, Imerman MB, Sopranzetti BJ (2013) Liquidity, leverage, and Lehman: A structural analysis of financial institutions in crisis. Fordham School of Business Research Paper No 2279686 45: 117-139.

5. Gunaratha V (2013) The degree of financial leverage as a determinant of financial risk: an empirical study of Sri Lanka. $2^{\text {nd }}$ International Conference on Management and Economics Paper.

6. Li L, Pornchai C (2014) Income structure, competitiveness, profitability, and risk: evidence from Asian banks. Review of Pacific Basin Financial Markets and Policies 17(3): 1450015.

7. Cheng LY, Wang MC, Chen KC (2014) Institutional investment horizons and the stock performance of private equity placements: evidence from the Taiwanese listed firms. Review of Pacific Basin Financial Markets and Policies 17(2): 1-30.

8. Gunarathna V (2016) How does financial leverage affect financial risk? an empirical study in Sri Lanka. Amity Journal of Finance 1(1): 57-66.

9. Park JC, Ali FD, Cedric M (2019). Investor sentiment and aggregate stock returns: the role of investor attention. Review of Quantitative Finance and Accounting 53(2): 397-428.

10. Allen F Gale D (1992) Stock Price Manipulation. Review of Financial Studies 5(3): 503-529. 
11. Basu Devraj, Streme, Alexander (2007) CAPM and time-varying beta: the cross-section of expected returns. SSRN Working Paper Series.

12. Chatterjea A, Cherian, Joseph A, Jarrow, Robert A (2001) Market Manipulation and Corporate Finance: A new Perspectives.

Financial Management Association International 22(2): 200-209.

13. Ramon PDG, Sangphill K (2003) The CAPM and beta in an imperfect market. SSRN Working Paper Series pp. 1-5.

14. Emilios A (2015) Bank leverage ratios and financial stability: A micro and macroprudential perspective. Working Paper No. 849, Levy Economics Institute pp. 1-46.

15. Galagedera DUA (2007) An alternative perspective on the relationship between downside beta and CAPM beta. Emerging Markets Review 8(1): 4-19.
16. Khwaja A, Asim Ijaz, Mian Atif (2005) Unchecked intermediaries: Price manipulation in an emerging stock market. Journal of Financial Economics 78(1): 203-241.

17. Martin K, Sweder VW (2012) On risk, leverage and banks: Do highly leveraged banks take on excessive risk? Tinbergen Institute Discussion Paper TI 12-022/2/DSF31.

18. Dima Rahman (2013) Are banking systems increasingly fragile? investigating financial institutions' CDS return extreme co-movements. Quantitative Finance 14(5): 805-830.

19. Thomas S (2013) Measuring marginal risk contributions in credit portfolios. Quantitative Finance 13(12): 1915-1923.

20. Andrew A, Joseph C (2007) CAPM over the long run: 1926-2001, Journal of Empirical Finance 14(1): 1-40.

21. ADB, Vietnam (2010) Fact Sheet.

For possible submissions Click below: 